\title{
Assessing fluvial flood risk in urban environments: a case study
}

\author{
Elisa Longo ${ }^{1, a}$, Giuseppe Tito Aronica ${ }^{1}$, Giuliano Di Baldassarre ${ }^{2}$ and Micah Mukolwe ${ }^{3}$ \\ ${ }^{1}$ Messina University, Department of Engineering, 98166 Messina, Italy \\ ${ }^{2}$ Uppsala University, Department of Earth Sciences, 75236 Uppsala, Sweden \\ ${ }^{3}$ UNESCO-IHE, Institute for Water Education, 2611 AX Delft, Netherlands
}

\begin{abstract}
Nowadays, floods are among the most impactful calamities regarding costs. Looking at the natural hazards damage data collected in the International Disaster Database (EM-DAT), it is observable a significant increase over the past four decades of both frequency of floods and associated costs. Similarly, dramatic trends are also found by analyzing other types of flood losses, such as the number of people affected by floods, homeless, injured or killed.To deal with the aforementioned rise of flood risk, more and more efforts are being made to promote integrated flood risk management, for example, the Flood Directive 2007/60/EC. The main goals of this research are the estimation of flood damages using the KULTURisk methodology and the comparing of the projected costs with the observed one. The case study is the 2002 flood in Eilenburg. According to KULTURisk methodology, two major classes of data are considered to evaluate flood risk damage: hydraulic data as regards Hazard and economic information to assess Exposure and Vulnerability This study shows the possibility to extend the lesson learned with the Eilenburg case study in other similar contexts.
\end{abstract}

\section{Introduction}

The economic impact of floods has grown significantly over the past four decades. In particular, looking at the natural hazards damage data provided by the International Disaster Database [1] one can see a significant increase in terms of frequency of floods and related costs (Figure 1). Furthermore, similar trends could be also appreciated by analyzing other types of flood losses, such as the number of people affected by floods, homeless, injured or killed.

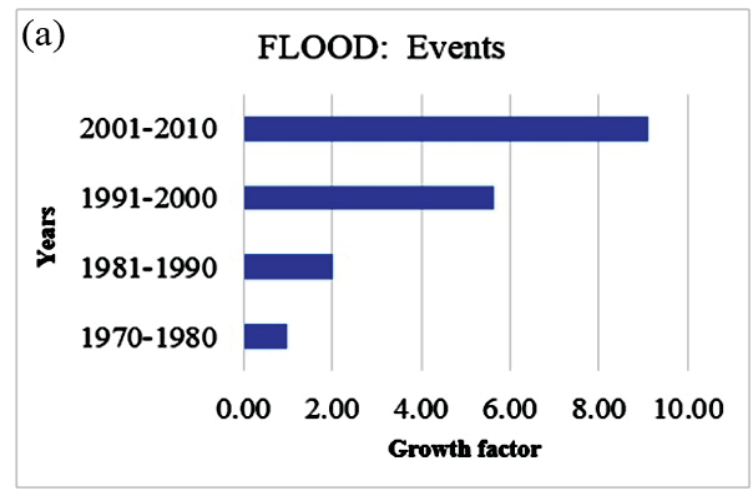

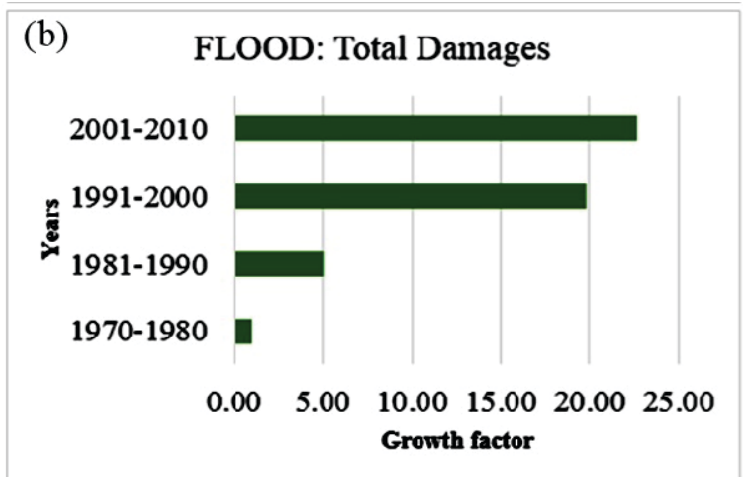

Figure 1. a) Evolution of the number of floods over the last forty years and b) cost trends associated with them.

To deal with the aforementioned surge in flood risk, in 2007 the European Community issued the Flood Directive [2]. One of the major introduction was the commitment to the member states to carry out flood risk maps and then to act appropriately to reduce the evaluated risk.

In the Flood Directive, it has been proposed to the member states of EC the following procedure:

* Undertake a Preliminary Risk Assessment (PFRA) by December 22, 2011, to identify areas of existing or foreseeable future potentially significant flood risk (referred to as Areas for Further Assessment, or AFA's );

\footnotetext{
${ }^{\mathrm{a}}$ Corresponding author: elisalongo.89@gmail.com
} 
* Prepare Flood Hazard and Risk Maps for the AFA's by December 22, 2013;

* Prepare Flood Risk Management plans by December 22, 2015, setting objectives for managing the flood risk wi+thin the AFA's and establishing a series of priority measures to achieve those aims.

Being flood risk changeable over the time, these maps should be reviewed every six years. According to the specific characteristic scenario, the maps must be made with different levels of accuracy. For instance, as regards the hydraulic hazard maps, depending on the return period, one or more of the following elements should be shown:

- the flood extent;

- water depths or water level;

- where appropriate, the flow velocity or the relevant water flow.

Many associations were born in Europe to pursue new useful solutions to mitigate the risk of flooding. Among these, can be included KUKTURisk, an EU funded research project aimed to develop a culture of risk prevention by evaluating the benefits of different risk prevention initiatives.

The research work focused, at first, on the assessment of flood damages through a computer code based on a recently developed method (KULTURisk, www.kulturisk.eu ). Subsequently, the estimated data were compared with the observed one to evaluate the reliability of the proposed code.

The study area has been the German municipality of Eilenburg, which in 2002 was subjected to a destructive flood event. According to KULTURisk methodology, two major classes of data are considered to evaluate flood risk damage, i.e.: hydraulic data for the Hazard (water depth, flow velocity and maximum hydrodynamic force) and economic statistics to assess Exposure and Vulnerability (agriculture and urban area and roads infrastructure).

The study shows the possibility to extend the findings obtained applying KULTURisk methodology for the Eilenburg case study in other similar scenario.

\section{Study site}

The study site selected is Eilenburg, a small town of about 17248 inhabitants of the Free State of Saxony, Germany, in the northern district of Saxony (Figure 2a). The city is crossed by the Mulde River, a tributary of Elbe, and the Mühlgraben bypass diverted from the main stream approximately $10 \mathrm{~km}$ upstream of Eilenburg.

In August 2002 a severe flood event hit many European countries along Elbe and Danube rivers and some their tributaries. Germany was affected, and Saxony was the German federal state most damaged. In particular, the city of Eilenburg and surroundings were completely flooded (Figure 2b), and inundation depths up to $5 \mathrm{~m}$ near the river and $3 \mathrm{~m}$ in the town were reached [3]. (a)

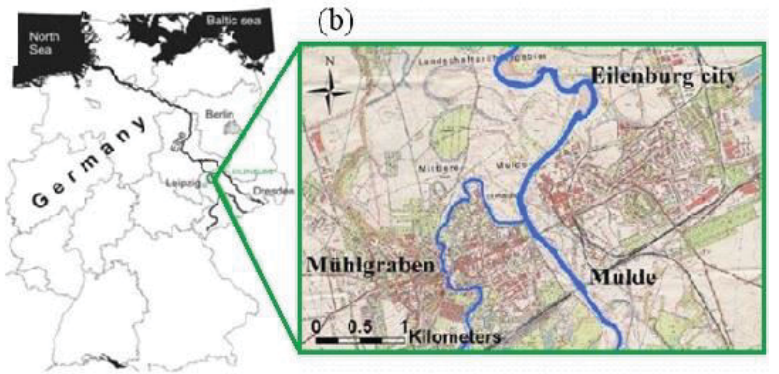

(c)

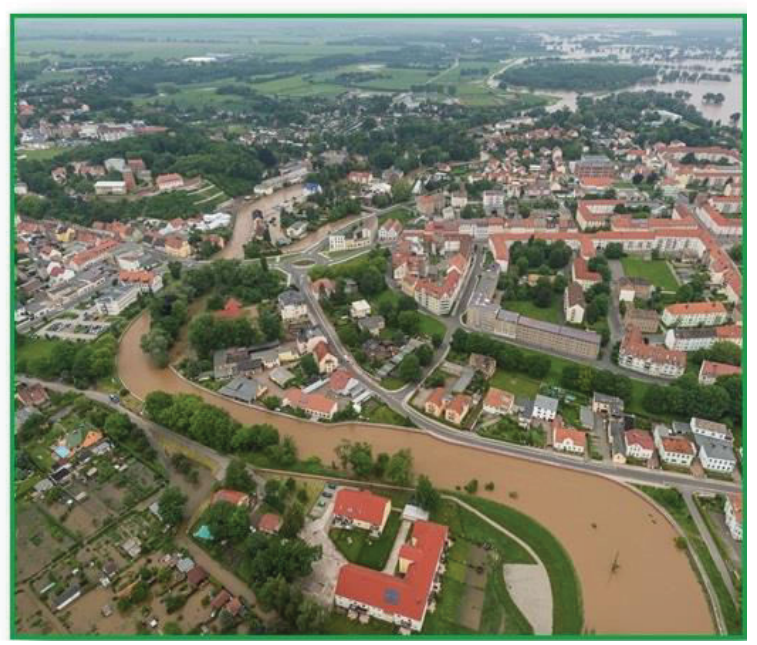

Figure 2. Territorial framework of the river Elbe (a), topographic map of Eilenburg (b) and a photo of Eilenburg during the 2002 flood event (c).

\section{KULTURisk Methodology}

The KULTURisk methodological framework and its operational approach SERRA (Socio-Economic Regional Risk Assessment) are developed upon the wellestablished Regional Risk Assessment literature, with specific focus on:

- the integration of physical/environmental dimensions and the socio-economic ones;

- the consideration of social capacities of reducing risk;

- the economic valuation of risk that goes beyond the direct tangible costs for decision support on risk mitigation measures;

- the integration of Climate Change Adaptation (CCA) in Disaster Risk Reduction (DRR).

The regional risk assessment focused on the analysis of the physical/environmental aspect of the flood hazard on the receptor characterized by the level of vulnerability (susceptibility) of the receptor. As suggested by the Flood Directive (2007/60/EC), the SERRA methodology considers the following receptors:

- people;

- economic activities, including:

$>$ Buildings

$>$ Infrastructure (roads)

$>$ Agriculture

- natural and semi-natural systems; 
- cultural heritage.

The main outputs of the method SERRA are GISbased maps of receptor related risks and of the total risk.[4]

\subsection{Input data}

Regarding the Eilenburg case study, the input data necessary for the running of the KULTURisk Matlab code are:

- for the HAZARD three hydraulic maps (Figure 3a, $3 \mathrm{~b}$ e $3 \mathrm{c}$ ):showing

$$
\begin{aligned}
& \circ \text { the water depth } \\
& \circ \text { the flow velocity } \\
& \circ \text { the maximum hydrodynamic force }
\end{aligned}
$$

- $\quad$ for the EXPOSURE and VULNERABILITY three maps (Figure 4a, 4b e 4c):displaying:

$$
\begin{aligned}
& \circ \text { the agricultural area } \\
& \circ \text { the urban area } \\
& \circ \text { the road network }
\end{aligned}
$$

(a)

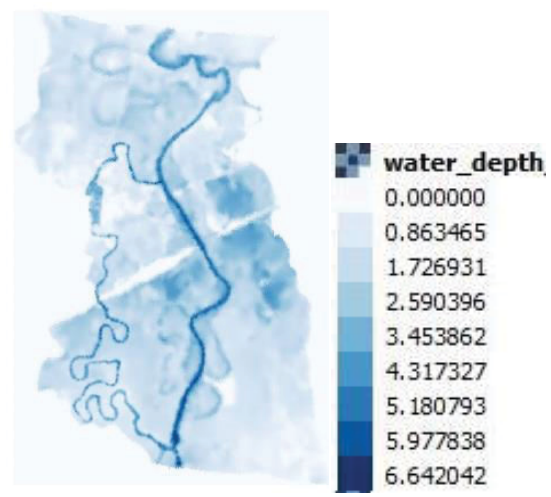

(b)

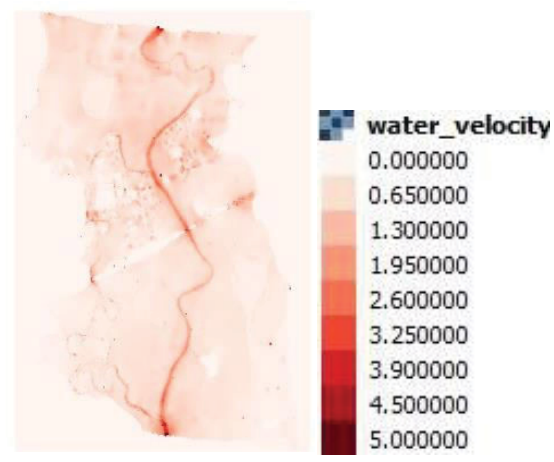

(c)

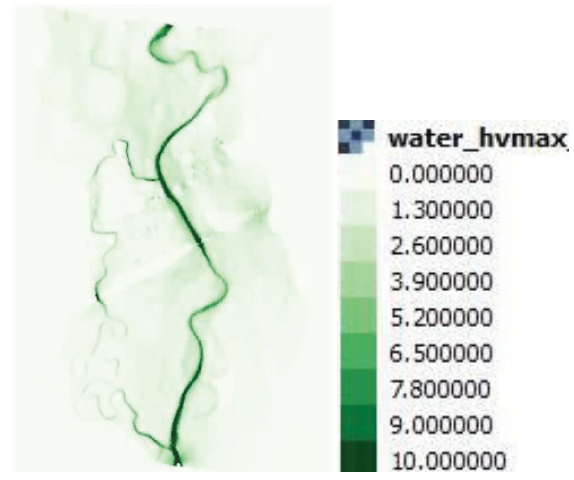

Figure 3. Hydraulic hazard maps containing different type of data such as (a) water depth, (b) flow velocity and (c) maximum hydrodynamic force

The hydraulic hazard maps have been processed using the software MLFP-2D (MultiLevel Flood Propagation 2-D) [5] and a GIS software (QGIS).

(a)

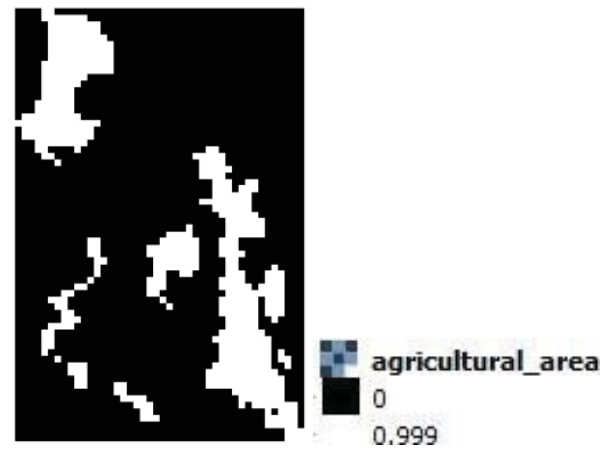

(b)

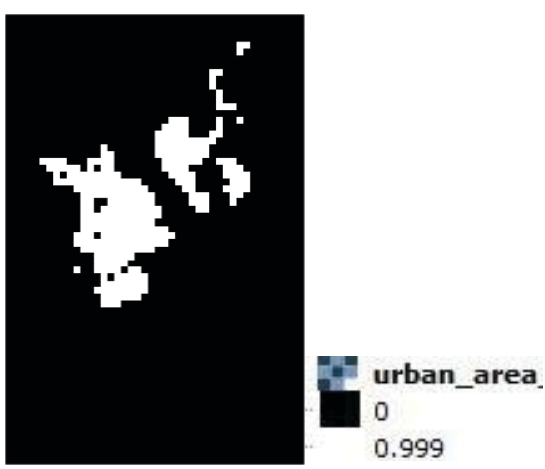

(c)

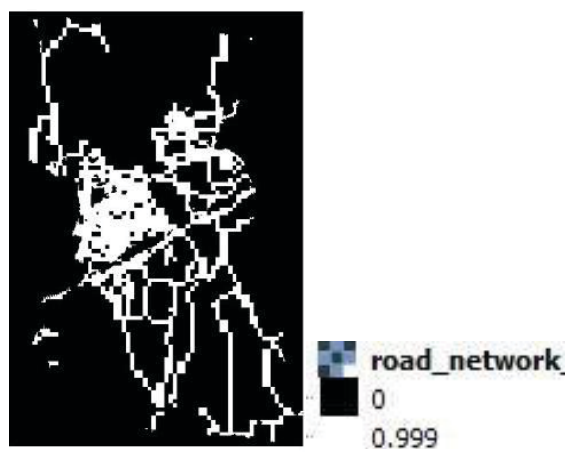

Figure 4. Exposure maps containing information about: (a) agricultural area, (b) urban area and (c) road network.

The exposure maps have been obtained based on the information provided by the Corine Land Cover and by the site Open Street Map, all of which are also processed on QGIS.With regards to the CLC maps, have been used three different versions to assess the changes in terms of exposure by the population:

- Corine Land Cover 1990

- Corine Land Cover 2000

- Corine Land Cover 2006

However, the more likely to the 2002 urban and agricultural situation of Eilenburg seems (and thus reported in Figure 4b and 4c) the CLC 2000. 


\subsection{Output data}

The KULTURisk Matlab code returns as output:

- $\quad$ six different output maps

- a summary table

For example, I show the maps of the combination with CLC 2000 and a summary table of the results

(a)

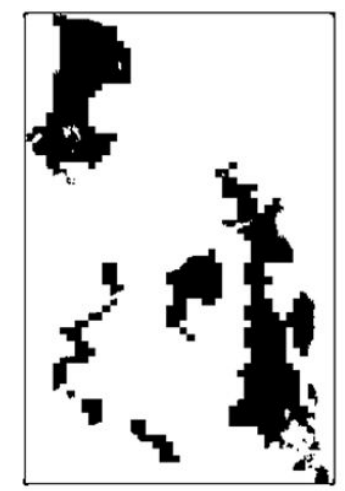

AGRICULTURAL DAMAGE

(Euros per 100 sq.m)

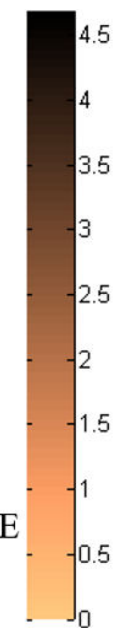

(b)

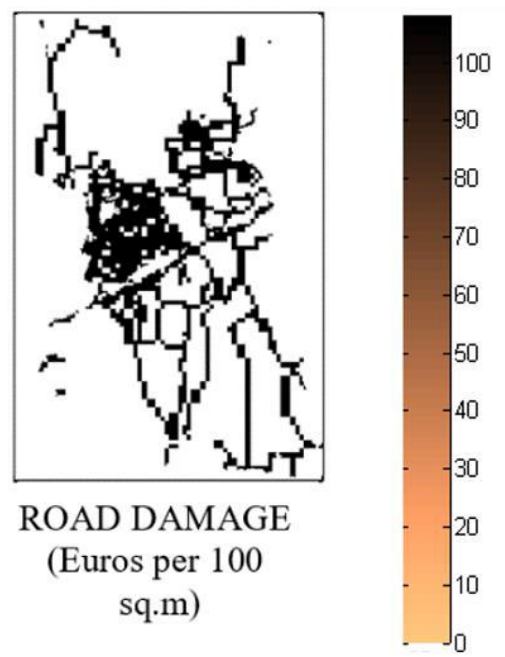

(c)

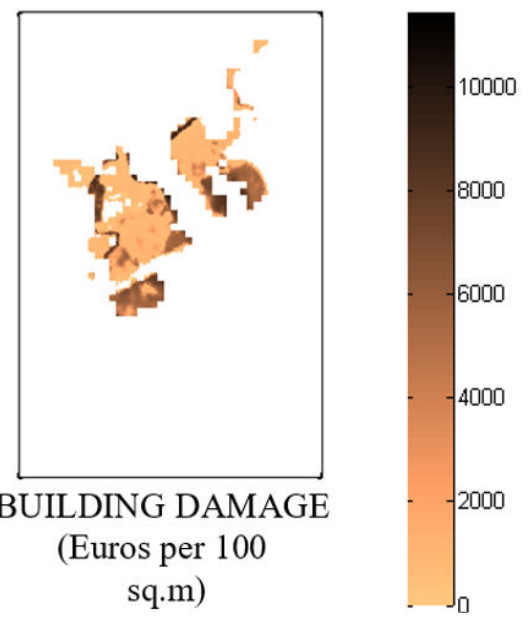

(d)

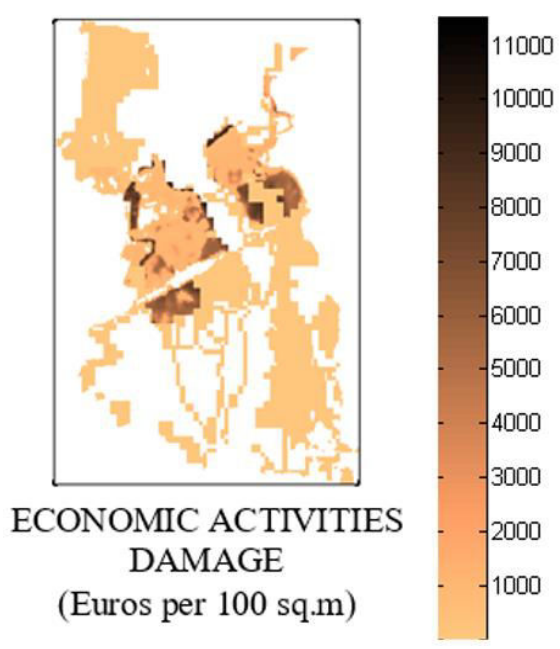

(e)

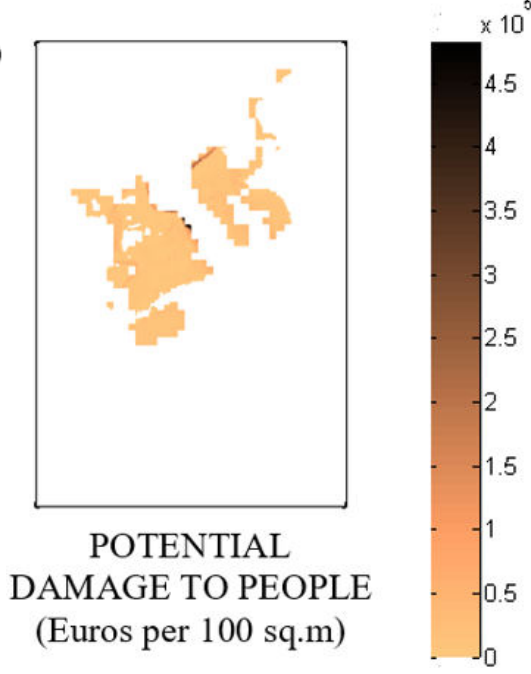

(f)

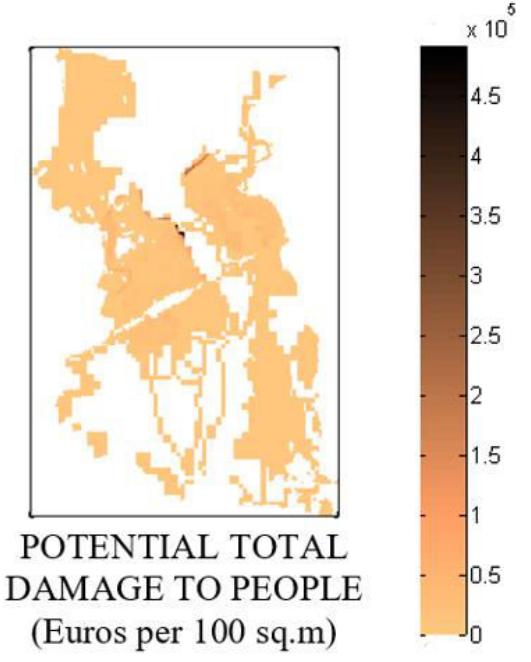




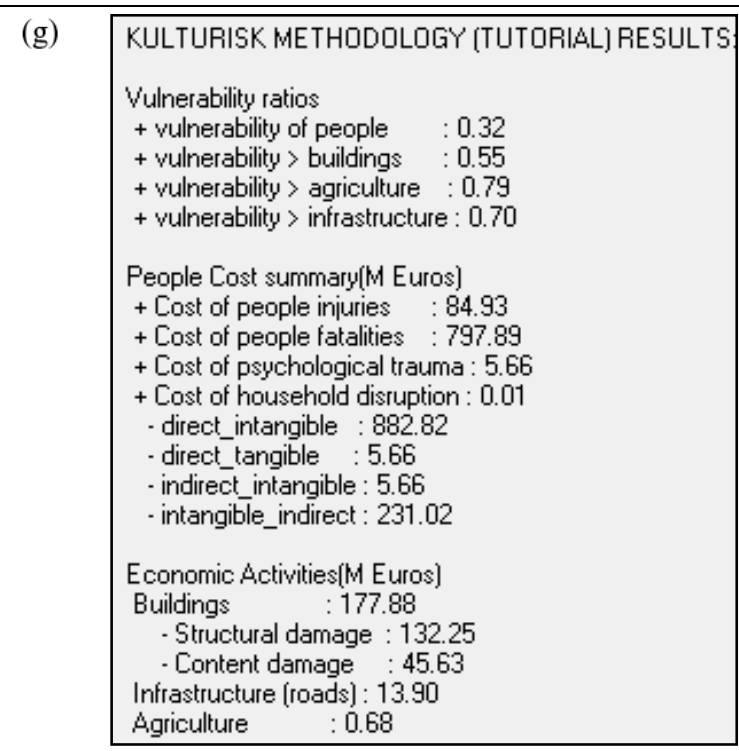

Figure 5. The main outputs provided by KULTURisk Matlab code: a) to (f) flood risk damage maps and (g) a summary table of the results

\section{Comparison and conclusion}

Insurance companies [6] provided the observed data. At first sight, by comparing between the two types of data (Table 1) it could be found a good correspondence in terms of orders of magnitude, which is already a very good sign about the reliability of KULTURisk procedure.

\begin{tabular}{|c|c|}
\hline \multicolumn{2}{|c|}{ OBSERVED DATA } \\
\hline $\begin{array}{c}\text { Total eligible repair cost for } \\
\text { damage to residential } \\
\text { buildings in August 2002 }\end{array}$ & 77.12 (M Euros) \\
\hline \multicolumn{2}{|c|}{ ESTIMATED DATA } \\
\hline \multicolumn{2}{|c|}{ Buildings } \\
Structural
\end{tabular}

Table 1. Comparison between the observed data and the estimated one

Despite this, the estimated damage is anyway greater than the observed one. This can be linked to the fact that probably not everyone has received a monetary compensation deriving from the flood because of the absence of precautionary measures [7].

In conclusion, the KULTURisk methodology has showed a good applicability to estimate in advance the damage caused by a potential flood. Therefore, the results confirm the possibility of extending the procedure to any other operating context.

\section{References}

1. EM-DAT (2014).The ofda/cred international disaster database www.emdate.be

2. EU (2007) "European Flood Directive: DIRECTIVE 2007/60/EC OF THE EUROPEAN PARLIAMENT AND OF THE COUNCIL of 23 October 2007 on the assessment and management of flood risks"

3. Fabio P., Novel techniques for incorporating uncertainty concepts in flood risk mapping, Ph.D. dissertation, The University of Palermo, Palermo, 2010

4. Giupponi C., Mojtahed V., Gain A. K., Balbi S. \& Biscaro C. Integrated Risk Assessment of Water Related Processes, Hydro-Meteorological Hazards, and Disasters, ed: Paolo Paron \& Giuliano Di Baldassarre, Elsevier Book series on Hazards and Disasters, Forthcoming 2014.

5. Aronica et al 2008

6. Apel H., Aronica G. T., Kreibich H., Thieken A. H. , Flood risk analyses - how detailed do we need to be?, Natural Hazards and Earth System Sciences, 2009, 49:79-98

7. Social vulnerability and the 2002 flood - COUNTRY REPORT GERMANY (MULDE RIVER), November 2006, Floodsite 